\title{
Altered immunoreactivity of islet amyloid polypeptide (IAPP) may reflect major modifications of the IAPP molecule in amyloidogenesis
}

\author{
Z . M a ${ }^{1}$, G . T. Westermark ${ }^{1}$, Z .-C . L i ${ }^{1}$, U . E ngström² ${ }^{2}$, P. Westermark ${ }^{1}$ \\ ${ }^{1}$ Department of Pathology I, Linköping University, Linköping, Sweden \\ ${ }^{2}$ Ludwig Institute of Cancer Research, Uppsala Branch, Uppsala, Sweden
}

Summary We have developed a mouse monoclonal antibody against rat/mouse islet amyloid polypeptide (IAPP). The antibody recognises an epitope in the $\mathrm{N}$-terminal part of the molecule, which is conserved between different species. The antibody immunohistochemically labelled beta cells in normal islets of most different mammalian species including man and in one avian species. Previous immunohistochemical studies of human pancreatic tissue from individuals with non-insulin-dependent diabetes mellitus (NIDDM) have revealed a paradoxical and unexplained lack of IAPP immunoreactivity in beta cells close to amyloid in spite of the presence of IAPP mRNA. In contrast to these findings we show that the newly developed monoclonal IAPP antibody strongly labels such beta cells while islet amyloid deposits which are labelled by polyclonal antisera do not bind the monoclonal antibody. These findings with the polyclonal antisera and the monoclonal antibody indicate that IAPP undergoes one or several structural changes during the amyloidogenesis. Knowledge of these structural changes that may include abnormal folding or chemical modification of IAPP is probably important for the understanding of the amyloidogenesis and the pathogenesis of the islet lesion in NIDDM. [Diabetologia (1997) 40: 793-801]

Keywords Islet amyloid polypeptide, monoclonal antibody, non-insulin-dependent diabetes mellitus, immunohistochemistry, deposits.
Islet amyloid polypeptide (IAPP; amylin) is a putative polypeptide hormone, in humans it is expressed mainly by the beta cells of the islets of Langerhans. It is co-stored with insulin in the secretory granules [1], where it is located in the outer, translucent zone [2]. IAPP is a 37-amino acid polypeptide with almost $50 \%$ identity with the neuropeptide calcitonin generelated peptide (CGRP) [3, 4]. Like CGRP, IAPP is C-terminally amidated and has a disulphide bridge close to its N-terminus. The sequence differences between the two peptides are mainly located in the central part of the molecules and there is a 10 amino acid

Received: 9 January 1997 and in revised form: 18 March 1997

Corresponding author: Dr. P. Westermark, Department of Pathology, University Hospital, S-581 85 Linköping, Sweden A bbreviations: CGRP, calcitonin gene-related peptide; IAPP, islet amyloid polypeptide; MAb, monoclonal antibody; NIDDM, non-insulin-dependent diabetes mellitus. segment (positions 20-29) which in humans is completely different from other species. However, the interspecies differences that exist in the IAPP amino acid sequence are also mainly located in the 20-29 segment [5-7].

Many groups have made antibodies to human or rat IAPP. The immunogen has been either full-length IAPP or segments of the molecule. Thus, rabbit antisera can be made against the 20-29 segment of human IAPP. Due to sequence differences between species in this part of the IAPP molecule, such antisera do not cross-react with rat or mouse IAPP in immunohistochemistry and it does not react with CGRP. On the other hand, it has turned out to be very difficult to obtain polyclonal antisera to human or rat/ mouse full-length IAPP that do not cross-react with CGRP. Thus, almost all commercially available polyclonal IAPP antisera show significant cross-reaction with CGRP. The cross-reaction is problematic in immunohistochemistry since both polypeptides can 
sometimes be found at identical locations. Thus, it has recently been shown in the rat that IAPP is a neuropeptide present in some CGRP-positive neurones [8]. Therefore we thought that a monoclonal antibody (MAb), not cross-reacting with CGRP, should be of great potential value. We have developed a murine $\mathrm{MAb}$ to IAPP which is useful for immunohistochemistry on paraffin-embedded tissue material. This antibody cross-reacts with IAPP in several different vertebrates including humans.

Differences in the 20-29 segment of IAPP between species seem to explain why only certain species such as human and cat develop amyloid in their islets [9]. However, the pathogenesis of islet amyloid in non-insulin-dependent diabetes mellitus (NIDDM) is not well understood. In addition to an amyloidogenic IAPP structure, over-production resulting in an abnormally high local IAPP concentration has been suggested to be of importance [10]. Experiments with transgenic mice carrying the human IAPP gene and highly over-expressing human IAPP [11-14], have shown that in addition other, so far undetermined factors are of importance in the amyloidogenesis and the beta-cell lesion in NIDDM. In a combined immunohistochemical and in situ hybridization study we found a strongly reduced IAPP immunoreactivity in spite of the presence of IAPP mRNA in beta cells close to islet amyloid deposits [15]. With the use of the newly developed monoclonal antibody to IAPP in an immunohistochemical study of tissue material from patients with and without NIDDM we got unexpected results that may shed some light on these earlier findings.

\section{Materials and methods}

Production of monoclonal antibody. MAbs were produced using standard protocols $[16,17]$. Full-length, C-terminally amidated rat/mouse IAPP was synthesized by Multiple Peptide Systems (San Diego, Calif., USA). Analysis by mass spectrometry revealed the expected mass. IAPP was conjugated to keyhole limpet hemocyanin (KLH) (Sigma, Stockholm, Sweden) with the aid of 1-ethyl-3-(3-dimethylaminopropyl) carbodiimide (Sigma) as described $[18,19]$. Female BALB/c mice were immunized intraperitoneally with $100 \mu \mathrm{g}$ KLH-IAPP in $0.5 \mathrm{~mol} / \mathrm{l} \mathrm{NaCl}$, mixed with Freund's complete adjuvant (Difco Laboratories, Detroit, Mich., USA) for the first injection. For subsequent injections Freund's incomplete adjuvant was used once a week. Blood was taken orbitally at regular intervals, diluted 1:100-1:800 and checked immunohistochemically on the islets of mouse pancreatic sections for the presence of IAPP antibodies. Three positive mice were boostered, and 3 days later killed by cervical dislocation and the spleen removed. Splenocytes were fused at a proportion of 10:1 with mouse non-secreting myeloma cells (line SP2/0) using $50 \%$ polyethylene glycol 4000 (Boehringer Mannheim, Mannheim, Germany). Fused cells were incubated in RPMI 1640 medium (Gibco BRL, Täby, Sweden) containing 15\% fetal bovine serum at $+37^{\circ} \mathrm{C}$ and $5 \% \mathrm{CO}_{2}$ for $2 \mathrm{~h}$, diluted to $5 \times 10^{5} / \mathrm{ml}$ in the same solution and then mixed with new-born rat thymocytes $\left(5 \times 10^{4} / \mathrm{ml}\right)$ and seeded into 96-well microtitre plates (Costar, Cambridge, Mass., USA), at $100 \mu \mathrm{l} /$ well. After $24 \mathrm{~h}$ incubation, $100 \mu \mathrm{l} 2 \times$ HAT (Hypoxanthine, Aminopterin, Thymidine) selection medium was added to each well. One week later, half the medium was removed and replaced with the appropriate amount of $1 \times$ HAT selection medium.

Screening for and production of monoclonal antibodies. Screening of the MAb-producing hybrids was performed by immunohistochemistry on formalin-fixed paraffin embedded normal human and rat pancreatic material. For this, $5 \mu \mathrm{m} \mathrm{sec-}$ tions were deparaffinized and incubated with the respective undiluted supernatants at $+4^{\circ} \mathrm{C}$ overnight. Antibodies were visualized by the avidin-biotin method (see below). One hybridoma (4A5) which reacted specifically with islets was selected for MAb production and detailed studies. The hybridoma cell line was subcloned three times by limiting dilution prior to final mass culture.

Characterization of the monoclonal antibody 4A 5. The isotype of MAb 4A5 was determined by an isotyping kit (Inno-Lia Mouse MAb Isotyping, Innogenetics N. V., Zwijndrecht, Belgium) to be of IgG2 b $x$ type. The specificity of the MAb was studied by slot immunobinding. Peptides (Fig. 1) were dissolved in $0.1 \mathrm{~mol} / \mathrm{l}$ sodium carbonate buffer, $\mathrm{pH} 9.6$ and spotted $(5 \mu \mathrm{g}$ for each slot) on a hybridization transfer membrane (Hybond - C extra, Amersham, Stockholm, Sweden) using a MilliBlot slot blotter (Millipore, Bedford, Mass., USA). To prevent unspecific binding the membrane was blocked for $1 \mathrm{~h}$ at room temperature with $5 \%$ non-fat milk in $0.1 \mathrm{~mol} / \mathrm{l}$ Tris $\mathrm{HCl}$ buffer, $\mathrm{pH} 7.2$, containing $0.15 \mathrm{~mol} / 1 \mathrm{NaCl}$ (TBS) and $0.1 \%$ Tween 20 , and then incubated overnight at $+4{ }^{\circ} \mathrm{C}$ with 4A5 supernatant, diluted 1:200 or rabbit antiserum A110 to rat/mouse IAPP, diluted 1:2000 in TBS. After washing with three changes of TBS containing $0.1 \%$ Tween 20 , the membrane was incubated for $2 \mathrm{~h}$ with horseradish peroxidase-conjugated rabbit anti-mouse or swine anti-rabbit Ig (Dakopatts, Copenhagen, Denmark), diluted 1:1000. The immunoreaction was visualized with an ECL Western blotting detection system (Amersham) according to the instructions provided by the manufacturer. The specificity of MAb 4A5 was also tested by preabsorption of 4A5 supernatant with a final concentration of $200 \mu \mathrm{g} / \mathrm{ml}$ synthetic peptides including full-length human and rat/mouse-IAPP, rat IAPP8-37, IAPP7-17, human and rat IAPP20-29, human IAPP26-37, human N- and C-terminal IAPP flanking peptides, human insulin and human $\alpha$-CGRP.

Tissues. Paraffin-embedded human pancreatic material was available from the laboratory files and included normal human pancreatic tissue from patients undergoing surgery for pancreatic neoplasms and pancreatic tissue from individuals with and without NIDDM obtained at autopsy within 4-10 h after death. These specimens have been described previously [15]. Paraffin-embedded pancreatic tissue from different animal species was also available from the laboratory files.

Human and rat normal pancreatic tissue was immersionfixed in $2 \%$ paraformaldehyde- $0.5 \%$ glutaraldehyde in $0.1 \mathrm{~mol} / \mathrm{l}$ sodium phosphate buffer $\mathrm{pH} 7.6$ for $4 \mathrm{~h}$ and then embedded in Unicryl (Biocell, Cardiff, UK) at $+4{ }^{\circ} \mathrm{C}$.

Immunohistochemistry. Polyclonal rabbit antiserum A110 against rat IAPP has been described [20] and used at a dilution of 1:2000. Guinea pig antiserum to insulin was from Dako (Copenhagen, Denmark) and used at a dilution of 1:1000. The MAb 4A5 was used as supernatant diluted 1:100-1:200. Immunohistochemical studies were performed using the avidinbiotin method [21]. Deparaffinized sections were pretreated 


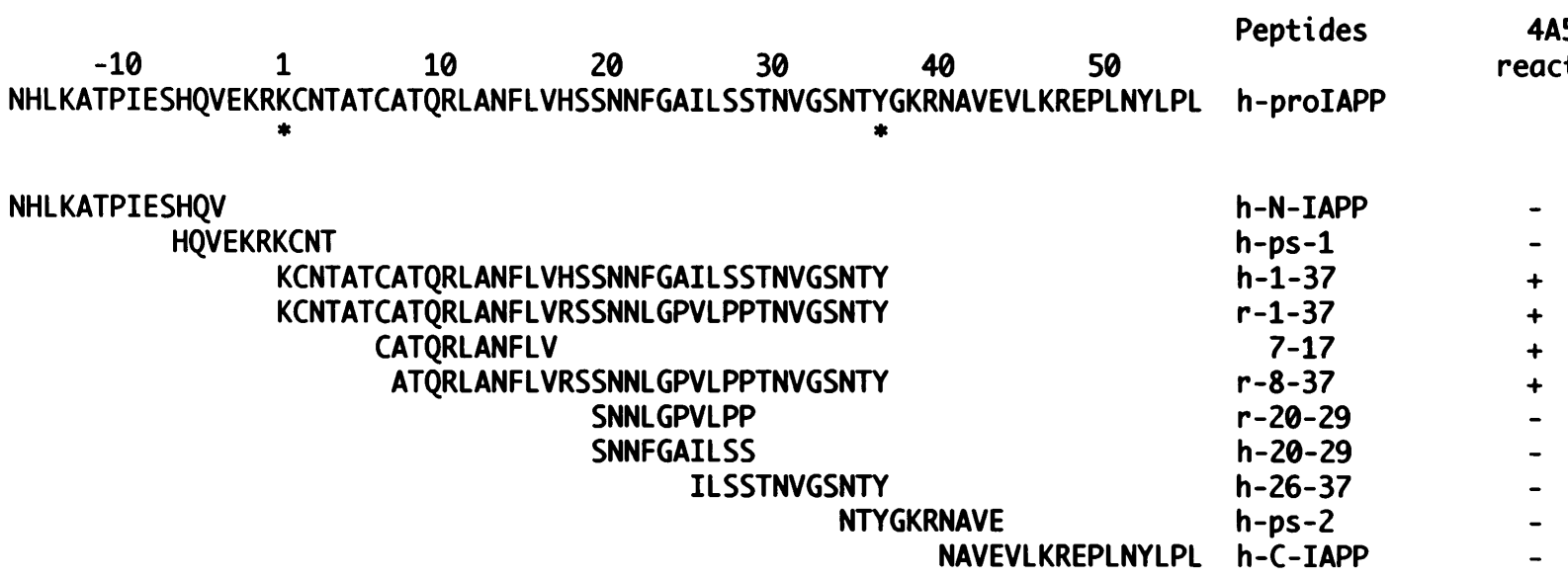

Fig. 1. Summary of slot blot analysis and absorption test of the monoclonal antibody 4A5 against synthetic polypeptides corresponding to different parts of the human (h-) or rat/mouse $(\mathrm{r}-)$ proIAPP. Numbers indicate amino acid residues of mature IAPP the limits of which are indicated by asterisks. Sequences corresponding to parts of the flanking peptides are N-IAPP and C-IAPP and sequences containing the two processing sites of proIAPP are shown as ps-1 and ps-2. The consensus sequence for reaction with 4A5 corresponds to IAPP8-17. The major part of human preproIAPP is above

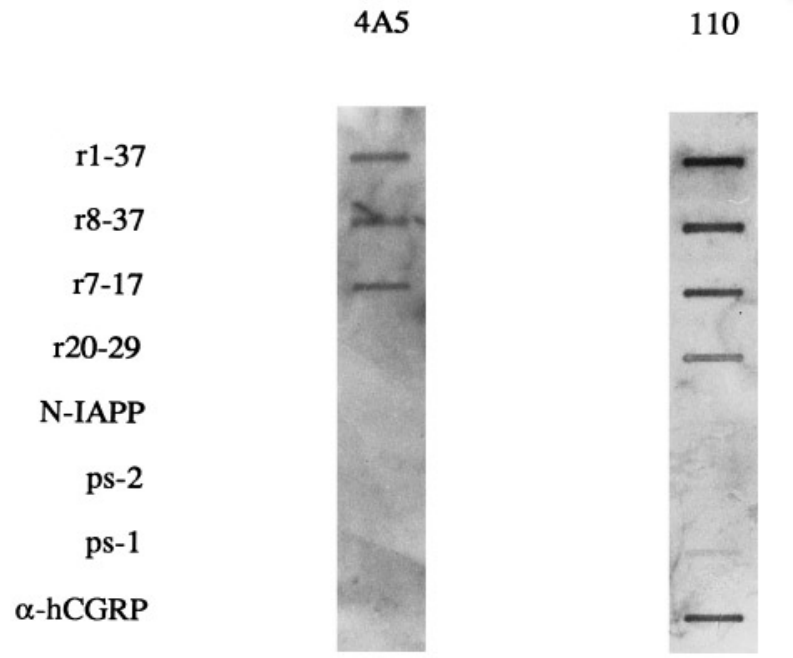

Fig. 2. Slot blot analysis of monoclonal antibody 4A5 and polyclonal rabbit antiserum A110 with different polypeptides (for explanation of abbreviations, see Fig. 1). Antiserum 110 reacts with CGRP in addition to IAPP-related polypeptides

with $0.3 \% \mathrm{H}_{2} \mathrm{O}_{2}$ in TBS for 30 min before incubation with the primary antibodies which was performed overnight at $+4^{\circ} \mathrm{C}$. After rinsing in TBS, the sections were incubated with biotinylated swine anti-rabbit immunoglobulin or goat anti-mouse immunoglobulin (Dakopatts, Copenhagen, Denmark), rinsed and the reaction was visualized with peroxidase-conjugated avidin followed by 3,3diaminobenzidine-tetrahydrochloride (DAB). For insulin detection, goat anti-guinea pig horseradish peroxidase-labelled antibodies (Dakopatts) was used. Negative control sections included replacement of the primary antibody with rabbit or mouse non-immune serum.
Initial immunohistochemical experiments with the MAb 4A5 gave inconclusive results. However, incubation of the sections in $0.01 \mathrm{~mol} / \mathrm{l}$ sodium citrate buffer, $\mathrm{pH} 6.0$, which was poured on hot $\left(+95^{\circ} \mathrm{C}\right)$ and then allowed to cool prior to the incubation with the MAb resulted in an even, strong and reproducible reaction. This pretreatment method was found to be superior to pretreatment with trypsin or microwaves.

Sections, adjacent to those used for immunohistochemistry were stained with alkaline Congo red [22] and examined for amyloid deposits in polarized light.

I mmune electron microscopy. The MAb used for immune electron microscopy was concentrated two times with the aid of membrane affinity separation system for purification of $\mathrm{IgG}$ (Kemila, Sollentuna, Sweden) and performed on ultrathin Unicryl sections from rat and human pancreata, mounted on formvar-coated nickel grids as described [23]. The reaction was visualized with $10 \mathrm{~nm}$ immunogold conjugate electron microscopy goat anti-mouse IgG (BioCell, Cardiff, UK).

Peptides. Rat/mouse C-terminally amidated full-length IAPP was from Multiple Peptide Systems (San Diego, Calif., USA). Human $\alpha$-CGRP was purchased from Bachem, Bubendorf, Switzerland. Human insulin was from Eli Lilly (Indianapolis, Ind., USA). Carboxy-terminally amidated peptides corresponding to parts of the human or rat/mouse IAPP, the processing sites of human proIAPP and the flanking peptides of human IAPP (Fig.1) were synthesized by automatic solidphase synthesis on a model 430A peptide synthesizer (Applied Biosystems, Foster City, Calif., USA). All peptides showed the expected molecular mass by mass spectrometry.

\section{Results}

Specificity of monoclonal antibody 4A 5. In slot blot analysis (Figs. 1 and 2) with different peptides including rat IAPP1-37, rat IAPP8-37, rat IAPP7-17, rat IAPP20-29, human N- and C-terminal flanking peptides, peptides including the proIAPP processing sites, human $\alpha$-CGRP and insulin, the MAb 4A5 showed a strong reaction with rat IAPP1-37, rat IAPP8-37 and rat IAPP7-17, but no reaction was seen with the other peptides. When MAb 4A5 was absorbed with the different peptides, only rat and human IAPP1-37, rat IAPP8-37 and rat IAPP7-17 completely abolished the immunohistochemical 
Table 1. Immunoreaction of the monoclonal antibody 4A5 with pancreatic islets in different species. The amino acid sequences of IAPP8-17 and CGRP8-17 are also shown

\begin{tabular}{|c|c|c|c|}
\hline IA PP 8-17 & Species & Ref. & 4A5 immunoreactivity \\
\hline A T Q R L T N F L T & Shrew & Unpublished & + \\
\hline A T Q R L A NFL V & Human & [4] & + \\
\hline A T Q R L A N F L V & Monkey & [35] & NT \\
\hline A $T$ Q R L A N F L I & Cat & [7] & + \\
\hline A $T$ Q R L A N F L I & Rabbit/hare & [20] & $(+)$ \\
\hline A $T$ Q $R$ L A N F L V & Dog & [35] & NT \\
\hline A $T$ Q $R$ L A N F L L & Raccoon & [36] & NT \\
\hline A $T$ Q R L A N F L V & Rat/mouse & [5] & + \\
\hline A $T$ Q R L T N F L V & Guinea pig & [6] & + \\
\hline A T Q R L T N F L V & Degu & [37] & - \\
\hline A $T$ Q R L A N F L V & Hamster & [5] & $(+)$ \\
\hline VTQR L A D F L V & Chicken & [38] & + \\
\hline T Q R L $\quad$ F L & Conserved in IAPP & & \\
\hline \multicolumn{4}{|l|}{ C G R P8-17 } \\
\hline $\mathrm{V} T \mathrm{TH} \mathrm{L}$ A $\mathrm{GLLS}$ & Human $\alpha$ and $\beta$ & [39] & \\
\hline $\mathrm{V} T \mathrm{TH} \mathrm{L} A \mathrm{~A} L \mathrm{~L} S$ & Rat $\alpha$ and $\beta$ & [39] & \\
\hline $\mathrm{V} T \mathrm{TH} \mathrm{L} A \mathrm{~A} L \mathrm{~L} S$ & Rabbit & [40] & \\
\hline $\mathrm{V} T \mathrm{TH} \mathrm{R} A \mathrm{~A} F \mathrm{~L} S$ & Chicken & [41] & \\
\hline
\end{tabular}

+ , Positive immunoreactivity; (+), weak immunoreactivity; -NT, not tested

reaction with normal rat islet tissue. The reactivity of MAb 4A5 is summarized in Figure 1. Absorption with the other peptides did not alter the immunoreactivity of MAb 4A5. A strong reactivity was obtained with rat IAPP1-37, rat IAPP8-37, rat IAPP7-17, rat IAPP20-29 and human $\alpha$-CGRP when the rabbit polyclonal anti IAPP antiserum A110 was applied in slot blot experiments.

Fig. 3a, b. Consecutive sections of a normal human islet labelled with the monoclonal antibody to IAPP 4A5 (a) and the polyclonal antiserum A110 to IAPP (b). The labelling pattern is the same in the two sections showing a labelling of islet beta cells. $\times 500$

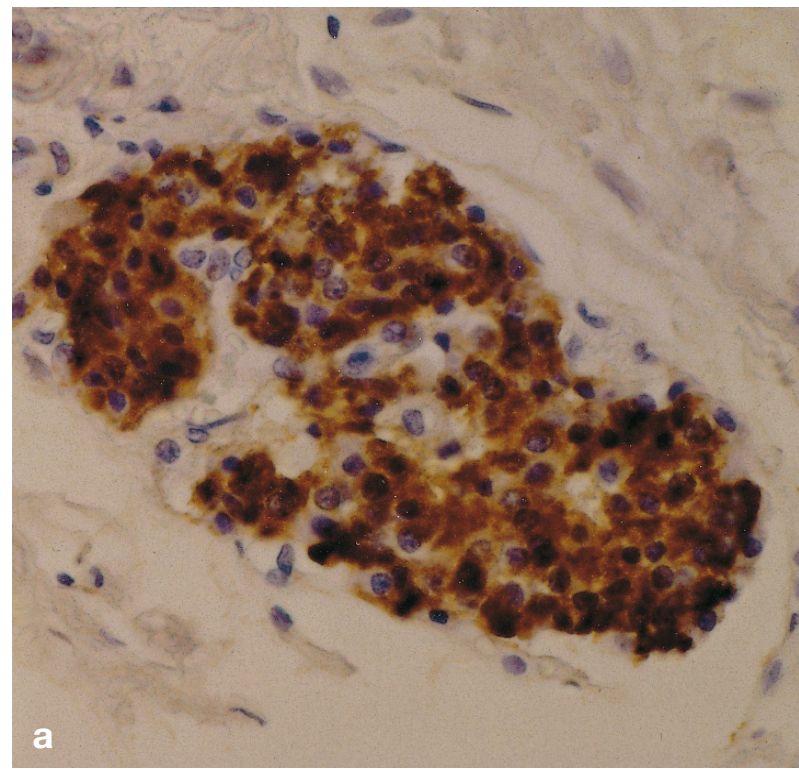

Immunohistochemical and immunocytochemical findings

Islets of $L$ angerhans. Immunoreactivity with $\mathrm{MAb}$ 4A5 was found in a majority of cells in normal human and rat islets of Langerhans. Consecutive sections labelled with MAb 4A5 and antiserum to IAPP (A110) revealed a similar distribution pattern of cells demonstrating that the labelled cells were beta cells (Fig. 3).

The reactivity of MAb 4A5 with the islets of Langerhans in different animal species is shown in Table 1 . As can be seen there is a broad cross reactivity of MAb 4A5 and beta cells of most studied species were labelled (Fig.4). The intensity of the reaction varied and the islets of a few animals exhibited only very faint labelling. These include rabbit and hare

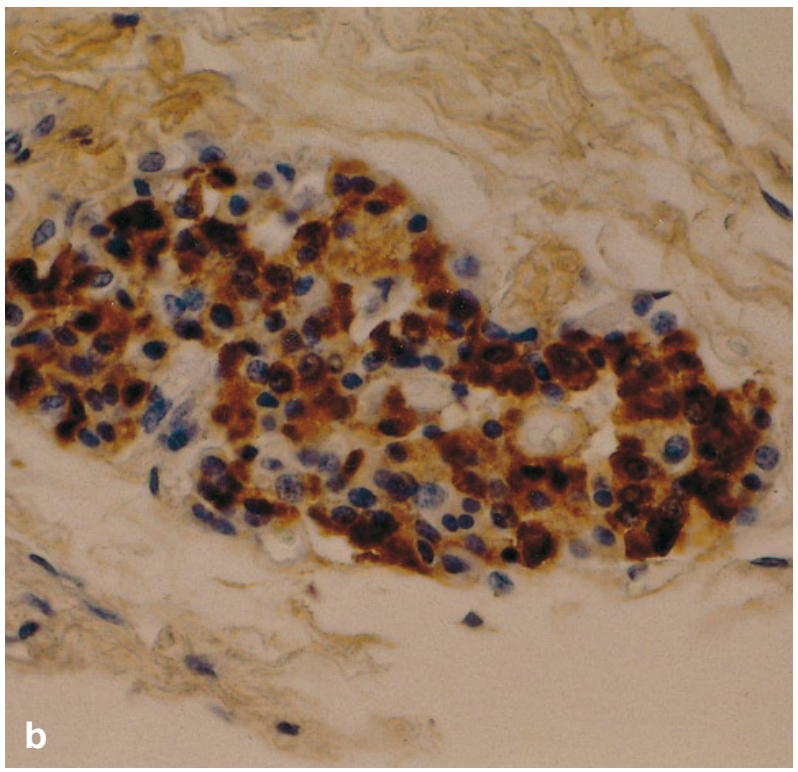



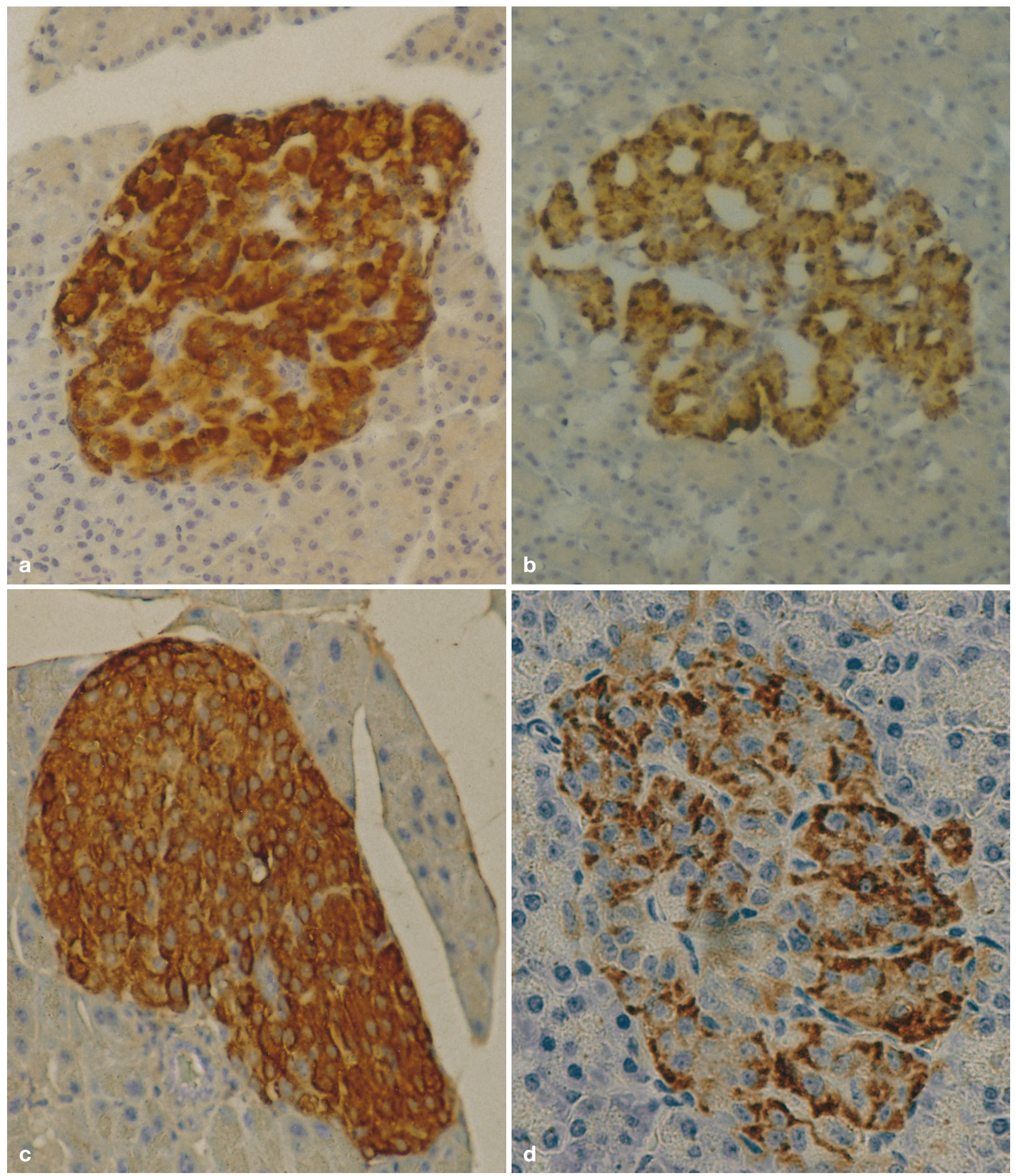

Fig. 4a-d. Pancreatic islets from different species labelled with the monoclonal antibody to IAPP 4A5: rat (a), chicken (b), mouse (c) and cat (d). $\times 300$ (a), 350 (b, c) and 600 (d)

which seem to express comparably little IAPP in beta cells [20]. The immunoreactivity in avian pancreatic tissue was localized to the small insulin-containing islets while the large glucagon-containing islets did not show any reactivity.

Electron microscopically, MAb 4A5 immunoreactivity was limited to beta-cell secretory granules. In contrast to insulin immunoreactivity, MAb 4A5 labelling was predominantly limited to the outer translucent part of the beta-cell granules (Fig. 5). Compared 


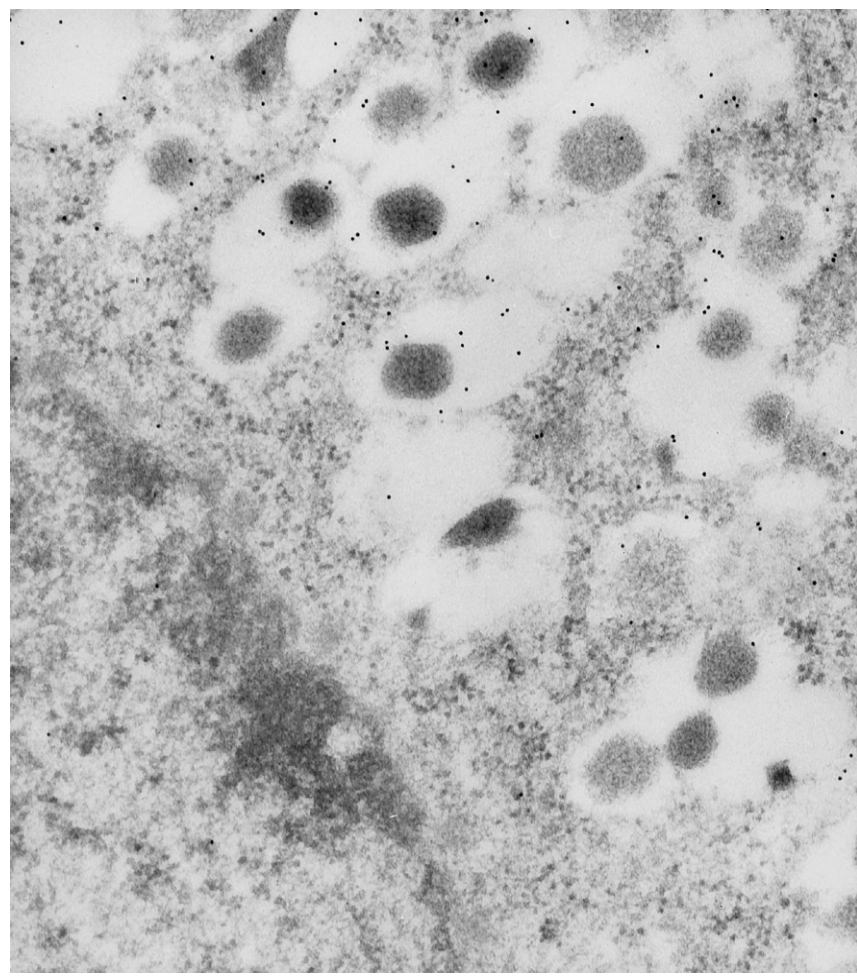

Fig. 5. Electron microscopy picture showing immunolabelling of normal human islet beta cell with the monoclonal antibody 4A5. The reaction is confined to the outer part of secretory granules where IAPP is stored. $\times 40000$

to labelling with antiserum to insulin and with polyclonal antiserum to IAPP the MAb 4A5 immunogold labelling was weak indicating that the antigenic epitope for MAb 4A5 is partly destroyed by the fixation and embedding procedure for electron microscopy.

IA P P-immunoreactivity in the pancreas of individuals with and without NIDDM. MAb 4A5 showed a strong immunolabelling of islet beta cells in the pancreata of patients with and without NIDDM (Tables 2 and 3; Fig. 6). Similar to what is seen in the normal human pancreas with polyclonal IAPP antiserum [15] (Fig. 3), the reactivity varied somewhat between individual beta cells in a given islet. Thus, some beta cells were more strongly labelled than others. This phenomenon was obvious in pancreata of diabetic as well as of non-diabetic individuals. When the polyclonal antiserum A110 was used, little or no IAPPimmunoreactivity was seen in beta cells in islets with amyloid (Tables 2 and 3; Fig. 6) in accordance with previous reports $[15,24]$. Interestingly, islet amyloid of diabetic and of non-diabetic individuals was almost completely devoid of reactivity with MAb 4A5 (Fig. 6) while the polyclonal antiserum A110 labelled islet amyloid strongly (Tables 2 and 3, Fig. 6). Pretreatment of the sections with hot citrate buffer did not alter the reactivity of beta cells or amyloid with antiserum A110. In order to study the possibility that formalin-fixation and paraffin embedding could change the reactivity with the antibodies, frozen sections of human pancreatic tissue with islet amyloid were labelled with MAb 4A5 and antiserum A110. However, identical results were obtained when compared to the paraffin-embedded material (not shown). Thus, pretreatment with hot citrate buffer was still necessary to obtain labelling of beta cells with MAb 4A5.

\section{Discussion}

We have developed a mouse MAb to rat/mouse IAPP. Immunohistochemically, the antibody shows reactivity with IAPP in different species but no cross-reactivity with CGRP was found in slot blot analysis. The epitope of the IAPP molecule could be determined to be situated between residues 8 and 17. This segment is within a conserved part of the IAPP molecule (Table 1) and differs in amino acid sequence from that of CGRP at some positions. The specificity to a conserved part of IAPP is in accordance with the wide cross reactivity between the

Table 2. Immunohistochemical reaction of islet beta cells and amyloid with monoclonal and polyclonal antibodies to IAPP in pancreatic tissue of individuals with non-insulin-dependent diabetes mellitus

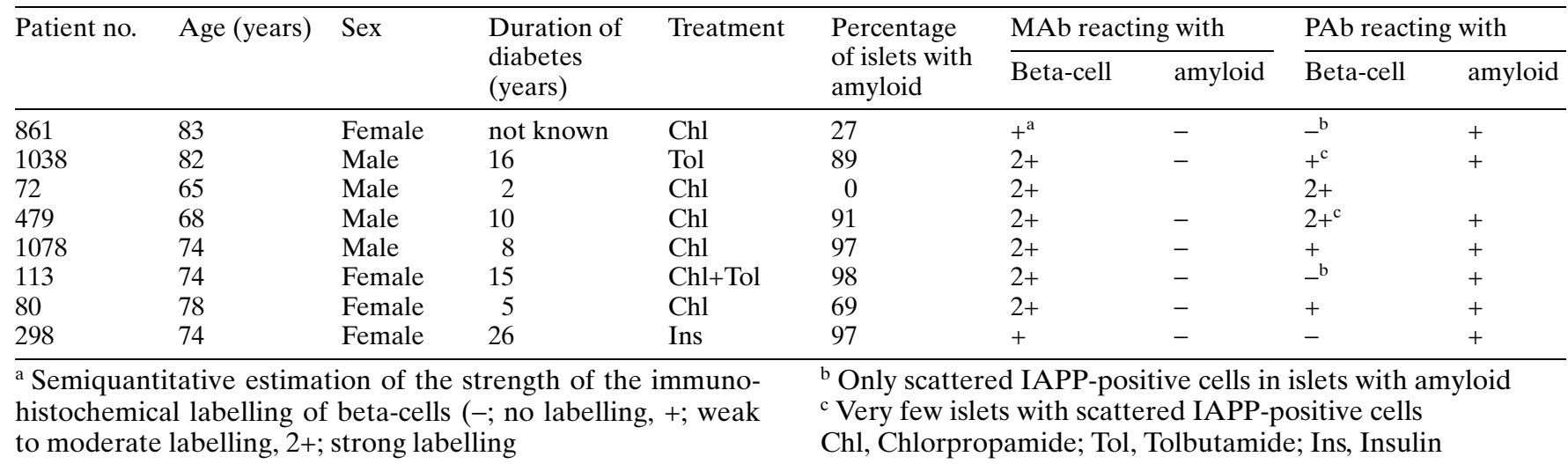




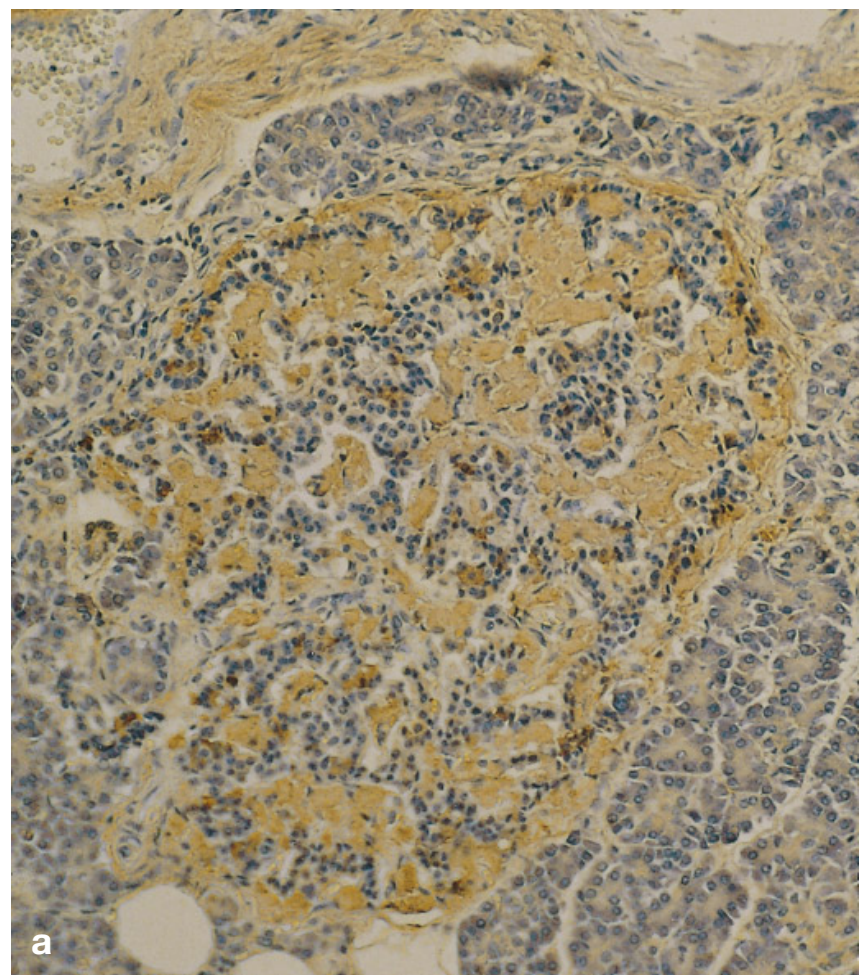

Fig. 6a, b. Representative islet of Langerhans from a patient with NIDDM, labelled with the polyclonal antiserum A110 against IAPP (a). Only few beta cells show a weak reaction while the amyloid is strongly labelled. The same islet labelled with the monoclonal antibody 4A5 against IAPP (b). The beta cells are strongly positive while the amyloid is negative. $\times 200$

tested mammalian and avian species found in the immunohistochemical study. Further studies with pancreata of reptiles have shown strong reactivity also in their islet beta cells (unpublished results).

Many MAbs demand frozen sections for their use in immunohistochemistry and therefore are of limited use. The method by which the MAb 4A5 was selected resulted in an antibody which reacts strongly with beta cells in pancreatic tissues that have been

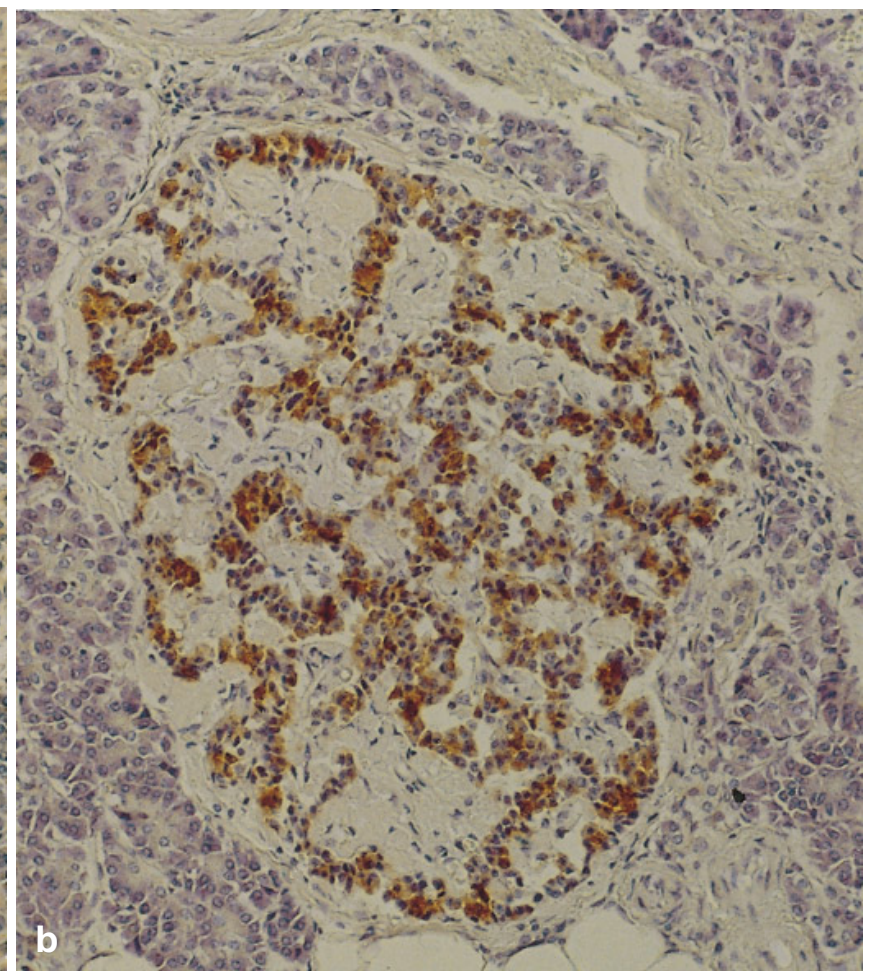

processed for routine diagnostic purposes. This processing includes formalin fixation and paraffin embedding. The insensitivity to fixation and embedding in combination with the avidity of the antibody gives it a great potential for use in immunohistochemical studies as shown in the present paper.

The pattern of reactivity of islet beta cells and islet amyloid with rabbit polyclonal antiserum A116 to human IAPP and with anti-insulin antiserum has been described earlier [15]. Antiserum A116 shows the same reactivity with human islet tissue as antiserum A110, used in this study. Shortly, while normal beta cells label strongly with different polyclonal anti IAPP antisera, beta cells in islets which contain amyloid deposits lack or have very low IAPP immunoreactivity in spite of the presence of IAPP mRNA. This immunoreactivity pattern was seen also in the present study when we used the polyclonal antiserum

Table 3. Immunohistochemical reaction of islet beta cells and amyloid with monoclonal and polyclonal antibodies to IAPP in pancreatic tissue of non-diabetic individuals

\begin{tabular}{|c|c|c|c|c|c|c|c|}
\hline \multirow[t]{2}{*}{ Patient no. } & \multirow[t]{2}{*}{ Age (years) } & \multirow[t]{2}{*}{ Sex } & \multirow{2}{*}{$\begin{array}{l}\text { Percentage of } \\
\text { islets with amyloid }\end{array}$} & \multicolumn{2}{|c|}{ MAb reacting with } & \multicolumn{2}{|c|}{ PAb reacting with } \\
\hline & & & & Beta-cell & amyloid & Beta-cell & amyloid \\
\hline 541 & 76 & Male & 15 & $t^{\mathrm{a}}$ & $\mathrm{NT}^{\mathrm{b}}$ & + & NT \\
\hline 1069 & 80 & Female & 0 & $2+$ & & $2+$ & \\
\hline 1049 & 81 & Male & 9 & $2+$ & - & $2+^{\mathrm{c}}$ & + \\
\hline 1029 & 78 & Male & 0 & $2+$ & & $2+$ & \\
\hline 1061 & 69 & Male & 6 & $2+$ & NT & $2+$ & NT \\
\hline
\end{tabular}

\footnotetext{
${ }^{a}$ Semiquantitative estimation of the strength of the immunohistochemical labelling of beta-cells (-; no labelling, +; weak to moderate labelling, $2+$; strong labelling

${ }^{\mathrm{b}}$ NT; not tested due to small amount of amyloid, difficult to identify in immunolabelling

${ }^{c}$ Only scattered IAPP-positive cells in islets with amyloid
} 
A110. The reactivity with antiserum to insulin is almost identical in beta cells of individuals with and without NIDDM [15, 24]. Islet amyloid is strongly IAPP immunoreactive (Fig. 6) but does not bind antibodies to insulin [24].

Several studies have shown that expression, storage and secretion of IAPP and insulin are normally parallel and at a fixed molar ratio [25, 26]. However, under certain pathophysiological conditions, a dissociation of the expression of the polypeptides may take place $[27,28]$. The findings that islet beta cells in association with islet amyloid deposits lack or have weak IAPP immunoreactivity [24] in spite of retained insulin immunoreactivity and presence of IAPP mRNA [15], have never been explained but was believed to reflect increased secretion and diminished intracellular storage of IAPP. The strong immunoreactivity that MAb 4A5 showed with beta cells also in islets with a large amount of IAPP-amyloid was therefore unexpected but indicates that IAPP is synthesized and stored in these beta cells but probably in an abnormal form.

Of considerable interest was also the finding that the most concentrated form of IAPP, islet amyloid, did not react with MAb 4A5. These findings cannot be explained with certainty at present but several possibilities exist. Formation of amyloid fibrils from a native protein is believed to take part as an offpathway aggregation by an intermediate at the folding-unfolding pathway [29,30]. Although most of the three-dimensional structure of the folded protein is present, there are some discrete differences in the tertiary structure between the native protein and the protein in the amyloid fibril. A loss of a normally present antigenic epitope may therefore occur in the amyloid fibrillogenesis and could explain the lack of immunoreactivity of MAb 4A5 with IAPP in its amyloid form. The loss of immunoreactivity of the polyclonal antisera to IAPP with islet beta cells close to amyloid deposits is more difficult to explain with this hypothesis.

An alternative explanation to the altered immunoreactivity of IAPP in association with the amyloidogenesis is a modification of IAPP, yet to be shown. In addition to the main fibril protein, other components are present in all forms of amyloid. These components include the amyloid P-component, which is a glycoprotein, and proteoglycans, especially heparan sulphate proteoglycan (HSPG). HSPG is present in islet amyloid [31] and the amyloidogenesis may take place in close association with the basement membrane [32]. Non-enzymatic glycation has been implicated in the pathogenesis of $\mathrm{A} \beta$ amyloid in Alzheimer's disease [33] and advanced glycation end products have been demonstrated immunohistochemically in islet amyloid in NIDDM (Bucala et al., unpublished data). Other post-translational modifications found in some amyloid materials include isomerization and racemization [34]. All these additional compounds and modifications which may be of great importance in the fibrillogenesis could also alter the antigenic properties of the IAPP molecule. Obviously further studies of the process of amyloid formation in the islets of Langerhans are highly indicated.

A cknowledgements. Supported by the Swedish Medical Research Council (5941), The Swedish Diabetes Association and the Novo-Nordic Research Fund. The authors wish to thank Helen Wilhelmsson and Christer Bergman for valuable assistance.

\section{References}

1. Lukinius A, Wilander E, Westermark GT, Engström U, Westermark P (1989) Co-localization of islet amyloid polypeptide and insulin in the B cell secretory granules of the human pancreatic islets. Diabetologia 32: 240-244

2. Westermark P, Li Z-C, Westermark GT, Leckström A, Steiner DF (1996) Effects of beta cell granule components on human islet amyloid polypeptide fibril formation. FEBS Lett 379: 203-206

3. Cooper GJ, Willis AC, Clark A, Turner AC, Sim RB, Reid KBM (1987) Purification and characterization of a peptide from amyloid-rich pancreases of type 2 diabetic patients. Proc Natl Acad Sci USA 84: 8628-8632

4. Westermark P, Wernstedt C, Wilander E, Hayden DW, O'Brien TD, Johnson KH (1987) Amyloid fibrils in human insulinoma and islets of Langerhans of the diabetic cat are derived from a neuropeptide-like protein also present in normal islet cells. Proc Natl Acad Sci USA 84: 3881-3885

5. Betsholtz C, Christmanson L, Engström U et al. (1989) Sequence divergence in a specific region of islet amyloid polypeptide (IAPP) explains differences in islet amyloid formation between species. FEBS Lett 251: 261-264

6. Nishi M, Chan SJ, Nagamatsu S, Bell GI, Steiner DF (1989) Conservation of the sequence of islet amyloid polypeptide in five mammals is consistent with its putative role as an islet hormone. Proc Natl Acad Sci USA 86: 5738-5742

7. Betsholtz C, Christmanson L, Engström U et al. (1990) Structure of cat islet amyloid polypeptide and identification of amino acid residues of potential significance for islet amyloid formation. Diabetes 39:118-122

8. Mulder H, Leckström A, Uddman R, Ekblad E, Westermark P, Sundler F (1995) Islet amyloid polypeptide (amylin) is expressed in sensory neurons. J Neurosci 15: 76257632

9. Westermark P, Engström U, Johnson KH, Westermark GT, Betsholtz C (1990) Islet amyloid polypeptide: pinpointing amino acid residues linked to amyloid fibril formation. Proc Natl Acad Sci USA 87: 5036-5040

10. Steiner DF, Ohagi S, Nagamatsu S, Bell GI, Nishi M (1991) Is islet amyloid polypeptide a significant factor in pathogenesis or pathophysiology of diabetes? Diabetes 40: 305 309

11. Höppener JWM, Verbeek JS, de Koning EJP et al. (1993) Chronic overproduction of islet amyloid polypeptide/amylin in transgenic mice: lysosomal localization of human islet amyloid polypeptide and lack of marked hyperglycaemia or hyperinsulinaemia. Diabetologia 36: 1258-1265

12. Verchere CB, D'Alessio DA, Palmiter RD, Kahn SE (1994) Transgenic mice overproducing islet amyloid 
polypeptide have increased insulin storage and secretion in vitro. Diabetologia 37: 725-728

13. Westermark GT, Benig Arora M, Fox N et al. (1995) Amyloid formation in response to $\beta$ cell stress occurs in vitro, but not in vivo, in islets of transgenic mice expressing human islet amyloid polypeptide. Mol Med 1: 542-553

14. Janson J, Soeller WC, Roche PC et al. (1996) Spontaneous diabetes mellitus in transgenic mice expressing human islet amyloid polypeptide. Proc Natl Acad Sci USA 93: 72837288

15. Westermark GT, Christmanson L, Terenghi G et al. (1993) Islet amyloid polypeptide: demonstration of mRNA in human pancreatic islets by in situ hybridization in islets with and without amyloid deposits. Diabetologia 36: 323-328

16. Brown G, Ling NR (1988) Murine monoclonal antibodies. In: Catty D (ed) Antibodies, vol. I. A practical approach. IRL Press, Oxford, pp 81-104

17. Langone JJ, van Vunakis H (1986) Immunochemical Techniques. Part I. Hybridoma Technology and Monoclonal Antibodes. Meth Enzymol 121

18. Gutkowska J, Thibault G, Januszewicz P, Cantin M, Genest J (1984) Direct radioimmunoassay of atrial natriuretic factor. Biochem Biophys Res Commun 122: 593-601

19. Gustavsson, Engström U, Westermark P (1994) Mechanisms of transthyretin (TTR) amyloidogenesis: antigenic mapping of transthyretin purified from plasma and amyloid fibrils and within in situ tissue localizations. Am J Path 144: 1301-1311

20. Christmanson L, Betsholtz C, Leckström A et al. (1993) Islet amyloid polypeptide in the rabbit and European hare: studies on its relationship to amyloidogenesis. Diabetologia 36: 183-188

21. Hsu SM, Raine L, Fanger H (1981) Use of avidin-biotin-peroxidase complex $(\mathrm{ABC})$ in immunoperoxidase techniques: a comparison between $\mathrm{ABC}$ and unlabeled antibody (PAP) procedures. J Histochem Cytochem 29: 577-580

22. Puchtler H, Sweat F, Levine M (1962) On the binding of Congo red by amyloid. J Histochem Cytochem 10: 355-364

23. Johansson B, Westermark P (1990) The relation of atrial natriuretic factor to isolated atrial amyloid. Exp Mol Path 52: 266-278

24. Westermark P, Wilander E, Westermark GT, Johnson KH (1987) Islet amyloid polypeptide-like immunoreactivity in the islet B cells of type 2 (non-insulin-dependent) diabetic and nondiabetic individuals. Diabetologia 30: 887-892

25. Pieber TR, Stein DT, Ogawa A et al. (1993) Amylin-insulin relationships in insulin resistance with and without diabetic hyperglycemia. Am J Physiol 265:E446-E453

26. Mulder H, Ahrén B, Sundler F (1996) Islet amyloid polypeptide (amylin) and insulin are differentially expressed in chronic diabetes induced by streptozotocin in rats. Diabetologia 39: 649-657
27. Ludvik B, Lell B, Hartter E, Schnack C, Prager R (1991) Decrease of stimulated amylin release precedes impairment of insulin secretion in type-II diabetes. Diabetes 40: 1615-1619

28. Mulder H, Ahrén B, Stridsberg M, Sundler F (1995) Nonparallelism of islet amyloid polypeptide (amylin) and insulin gene expression in rat islets following dexamethasone treatment. Diabetologia 38: 395-402

29. Wetzel R (1994) Mutations and off-pathway aggregation of proteins. Trends Biotech 12: 193-198

30. Kelly JW, Lansbury PTJ (1994) A chemical approach to elucidate the mechanism of transthyretin and $\beta$-protein amyloid fibril formation. Amyloid: Int J Exp Clin Invest 1: 186-205

31. Young ID, Ailles L, Narindrasorasak S, Tan R, Kisilevsky R (1992) Localization of the basement membrane heparan sulfate proteoglycan in islet amyloid deposits in type-II diabetes-mellitus. Arch Path Lab Med 116: 951-954

32. Westermark P (1994) Amyloid and polypeptide hormones: what is their inter-relationship? Amyloid: Int J Exp Clin Invest 1: 47-60

33. Smith MA, Taneda S, Richey PL et al. (1994) Advanced Maillard reaction end products are associated with Alzheimer disease pathology. Proc Natl Acad Sci USA 91: 5710-5714

34. Näslund J, Karlström AR, Tjernberg LO, Schierhorn A, Terenius L, Nordstedt C (1996) High-resolution separation of amyloid b-peptides: structural variants present in Alzheimer's disease amyloid. J Neurochem 67: 294-301

35. Ohagi S, Nishi M, Bell GI, Ensinck JW, Steiner DF (1991) Sequences of islet amyloid polypeptide precursors of an old world monkey, the pig-tailed macaque (macaca-nemestrina), and the dog (canis-familiaris). Diabetologia 34: $555-558$

36. Jordan KC, O'Brien TD, Johnson KH (1994) Sequence of raccoon IAPP supports importance of a specific structural motif in the development of pancreatic islet amyloidosis. Amyloid. Int J Exp Clin Invest 1: 160-164

37. Nishi M, Steiner DF (1990) Cloning of complementary DNAs encoding islet amyloid polypeptide, insulin, and glucagon precursors from a new world rodent, the degu, Octodon degus. Mol Endocrinol 4: 1192

38. Fan L, Westermark GT, Chan SJ, Steiner DF (1994) Altered gene structure and tissue expression on islet amyloid polypeptide in the chicken. Mol Endocrinol 8: 713-721

39. Breimer LH, MacIntyre I, Zaidi M (1988) Peptides from the calcitonin genes: molecular genetics, structure and function. Biochem J 255: 377-390

40. Eysselein VE, Reeve JR, Sternini C et al. (1991) Structural characterization of calcitonin gene-related peptide purified from rabbit intestine. Peptides 12: 289-295

41. Minvielle S, Cressent M, Delehaye MC et al. (1987) Sequence and expression of the chicken calcitonin gene. FEBS Lett 223: 63-68 